\title{
Article
}

\section{“Oh, You Shouldn't Have!" Understanding Key Factors Impacting Cut Flowers Gifting Preferences in Germany}

\author{
Meike Rombach ${ }^{1, *}$, David L. Dean ${ }^{2}\left(\mathbb{D}\right.$, Nicole J. Olynk Widmar ${ }^{3}\left(\mathbb{D}\right.$ and Vera Bitsch ${ }^{4}(\mathbb{C}$ \\ 1 Department of Land Management and Systems, Lincoln University, Lincoln 7647, New Zealand \\ 2 Department of Agribusiness and Markets, Lincoln University, Lincoln 7647, New Zealand; \\ david.dean@lincoln.ac.nz \\ 3 Department of Agricultural Economics, Purdue University, West Lafayette, ID 47907, USA; \\ nwidmar@purdue.edu \\ 4 School of Management and School of Life Sciences, Chair of Economics of Horticulture and Landscaping, \\ Technical University of Munich, 85354 Freising, Germany; bitsch@tum.de \\ * Correspondence: meike.rombach@lincoln.ac.nz
}

check for updates

Citation: Rombach, M.; Dean, D.L.; Olynk Widmar, N.J.; Bitsch, V. “Oh, You Shouldn't Have!" Understanding Key Factors Impacting Cut Flowers Gifting Preferences in Germany. Horticulturae 2021, 7, 368. https:/ / doi.org/10.3390/horticulturae7100368

Academic Editor: Christian Fischer

Received: 5 September 2021

Accepted: 2 October 2021

Published: 6 October 2021

Publisher's Note: MDPI stays neutral with regard to jurisdictional claims in published maps and institutional affiliations.

Copyright: (c) 2021 by the authors. Licensee MDPI, Basel, Switzerland. This article is an open access article distributed under the terms and conditions of the Creative Commons Attribution (CC BY) license (https:// creativecommons.org/licenses/by/ $4.0 /)$.

\begin{abstract}
Cut flower gifting preferences are relatively unexplored in Germany. This study proposes a model that investigates the impact of attitudinal, experiential, and socio-demographic factors on the cut flower gifting preferences of German consumers. For this purpose, an online survey with a representative sample of 978 German residents was conducted. Partial least squares structural equation modelling shows that active and passive engagement with plants and nature positively impact cut flower giving preferences through cut flower knowledge, cut flower fondness, and perceived versatility of cut flowers. For German women and men, the largest driver of cut flower giving preferences is the versatility of cut flowers. For women, cut flower fondness is the second largest driver of cut flower gifting preferences, whereas for men subjective knowledge was the second largest driver. Other socio-demographic factors (age, income, education) were not found to impact cut flower giving preferences.
\end{abstract}

Keywords: attitudes; experiences; German consumers; gift preferences; horticultural non-food product

\section{Introduction}

Gift giving is a custom found in many societies around the world. It is described as a social act, where a good is exchanged [1]. The social act occurs over time and distance, and includes three different phases: giving, receiving, and reciprocating. The essential point of this process is to build social ties and relationships. The act of giving builds on economic and symbolic values that both parties dedicate to the gift $[2,3]$.

With respect to the economic value of flowers, the underlying motives are prestige or other forms of impression making [4]. The symbolic value refers to motives such as love, care, friendship, sympathy, pleasure, need, want, or obligation [5-8]. In the obligation context, Joy (2001) describes the following relational paradox: as the giver approaches the recipient through giving, the recipient is in fact put into obligation. While giving seeks to reduce social distance, it is simultaneously increasing social distance, until a gift is given in return [9].

Gifts can be quite diverse and are not necessarily limited to tangible items. Service, time, ideas, money, or flowers are commonly given [9-12]. In fact, what is given is determined by the characteristics of the relationship between the giving and receiving parties. In personal as well as in business relationships [13], cut flowers serve as an appropriate gift item, used to transmit the underlying intent from flower giver to flower recipient. Effective transmission requires the recipient to understand the underlying message, in terms of context, value, and symbolism [14-16].

When buying fresh cut flowers as gifts, various studies emphasize the importance of understanding how consumers value cut flowers [10,17]. 
In Germany, consumers like to buy floral gifts from a local flower retailer [18], because they appreciate the florist's advice, social interaction, and the sensory stimulation in the flower shop $[19,20]$. Others buy in supermarkets or discounters, often due to budget and time constraints [21]. Regardless of whether consumers buy from specialized or general retailers, the sensory contact with cut flowers is important to them. In the buying situation, appearance, scent, price, and other product information are evaluated to estimate the flower quality and value $[13,22]$. Consumers desire characteristics such as good blooming quality and a long vase life since they enhance value and are more likely to make a good and lasting impression on the gift recipient $[10,13,23]$.

Other consumers buy cut flowers via online flower retailers, often because they want to buy at a particular time, they appreciate the convenience, or they want to take advantage of a delivery service [24]. Flower variety in online flower retail is comparable to physical retail, as both types of outlets offer single stem flowers, standard bouquets, and other floral products. In online retail, tools to customize orders allow buyers to build unique and personal flower arrangements [20,24]. The most popular cut flowers in Germany are roses, tulips, chrysanthemums, sunflowers, and gerberas. The flowers are available as single stems, or mono or multifloral bouquets and sold at weekly markets, garden centers, supermarkets, discounters, and specialized flower retail (see supplementary materials). Specialized flower retail refers to physical retailers and online retailers [19,20,24].

Flowers are also bought for one's personal use and enjoyment. In both cases, the purchase depends on socio-demographic backgrounds, personal experience, values, and lifestyle. In addition, both types of purchases are affected by trends in the flower market [25].

It is estimated that German consumers spend on average 39 Euros per capita per year for cut flowers [26]. Further details about German cut flower consumers and the giving context have yet to be explored. Given that consumer preferences for floral gifts are largely unexplored in Germany, this study seeks to fill this literature gap by exploring key factors thought to impact German residents' preferences for floral gifts including engagement with plants and plant knowledge, socio-demographic information, the versatility of cut flowers as a gift, as well as fondness associated with flowers.

\section{Literature Review}

Previous studies of German and other flower consumers have identified engagement with plants, plant knowledge, socio-demographic information, the versatility of cut flowers as a gift, and fondness associated with flowers as factors that impact German consumers' preferences for floral gifts. Given the presence of only a few consumer studies dedicated to cut flowers in Germany, the literature review borrows from the wider research context of agricultural products, such as ornamental plants and food products, which share characteristics with cut flowers, such as their perishability and limited shelf life.

\subsection{German Consumers' Engagement with Plants and Plant Knowledge}

Plant buyer engagement with plant products as well as their information-seeking practices have been examined by Lampert et al. (2012) [27]. Their study focused on Southern German consumers' preferences for palm plants and emphasized that consumers seek information about gardens and houseplants while shopping. Furthermore, they obtain information from gardening magazines, books, and TV shows, or from mail and email newsletters.

The engagement practices presented by Lampert et al. (2012) show passive information seeking practices, rather than "hands on" or active horticultural or gardening experience [27]. At present, the influence of active horticultural involvement and actual plant knowledge on German consumer preferences remains unexplored. Various recent German studies on the effects of houseplants on human wellbeing, as well research dedicated to supply chains for ornamental plants and flowers call for further investigation [28,29]. 
Similar findings have been presented by Pavia et al. (2020). The Brazilian study clearly indicates that consumers have either no or very little knowledge about cut flowers and ornamental plants. Their preferred information sources to read about flowers and plants are the Internet and social media, followed by personal advice obtained from a professional in the flower industry [30]. In contrast, recent US studies researching ornamental plant consumption, retail, and landscaping indicate some engagement with plants through gardening activities; however, their knowledge and information practices are widely unexplored [31-33].

Further evidence stems from agricultural product studies, which are comparable to cut flowers at least in their perishability, and suggest that consumers who have agricultural and hunting experience, have better perceived product knowledge, and this knowledge impacts their product preferences [34-40]. In conclusion, consumers' engagement with nature and plants, whether active or passive, has been shown to shape attitudes towards and understanding of decorative horticultural products, like ornamental plants and cut flowers. For the purposes of this research, attitudes and understanding are referred to as fondness for cut flowers and cut flower knowledge. Thus, the following hypotheses are proposed:

Hypothesis 1 (H1). German consumers' active engagement with nature and plants positively impacts their cut flower fondness.

Hypothesis 2 (H2). German consumers' active engagement with nature and plants positively impacts their subjective cut flower knowledge.

Hypothesis 3 (H3). German consumers' passive engagement with nature and plants positively impacts their cut flower fondness.

Hypothesis 4 (H4). German consumers' passive engagement with nature and plants positively impacts their subjective cut flower knowledge.

\subsection{Cut Flower Gift Versatility and Flower Fondness}

The purpose of any gift, including floral gifts, is often determined by the sentiment and values associated with it. The theory of consumption value is an important theoretical branch of literature in this context that emphasizes five values that are relevant for consumers when deciding whether to buy flowers as a gift [41]. These values include functional, emotional, epistemic, conditional, and social values. Sensory perception through touch or smell allows consumers to estimate flower quality when making a purchase decision; therefore, it relates to the functional value of the product. Emotional value stems from a consumer's emotional reaction toward the product, which can be stimulated through flower fragrance, location, and flower colors. Emotional value is therefore psychological in nature [41]. Epistemic value refers to the perceived curiosity and excitement from the purchase of a product, and desire for novelty. Novelty relates to flower variety, color, and smell. The conditional value of flowers refers to the performance of the product, which includes flower quality and consumer willingness to pay. Social value is characterized as the perceived benefit of flowers in a social context and setting, which ties the flower giver and recipient together [41].

In this context, previous studies such as Huang and Lin (2015) have identified floral gift buyers in Taiwan and their motivation and values [12]. Their study builds on a consumer survey with a multinominal regression analysis and highlights that perceived floral gift values including social, functional, and economic values determine the decision of whether to buy floral gifts or not. These values are tied to the particularities of the relationships between giver and recipient. While the economic value of the floral gift is crucial in family ties, social and expressive values are of importance in romantic relationships.

Yue and Behe (2010) investigated single stem cut flower preferences of US consumers. Their study was based on panel data, a multinominal regression analysis, and emphasized 
the symbolism of flower types and colors to convey different values and feelings [42]. Red roses are used to say, "I love you", while yellow carnations serve for apologies. For both occasions, daisies are considered inappropriate. Men and women appear to differ in their cut flower and color preferences. These vary based on socio-demographic characteristics, occasion, and message to be conveyed, and they change over time. Overall, women seem to be fonder of cut flowers than men, as they make the majority of flower purchases [42]. These results are aligned with the findings of Yue and Hall (2010) comparing traditional and specialty cut flowers, as well Rihn et al. (2011) $[11,13]$.

Rihn et al. (2011) suggest that flowers are an appropriate gift to cheer someone up, serve as a medium to bring back memories, convey emotions such as happiness, love, and sympathy, bring joy, and are a classic, safe gift that is appropriate for a variety of messages and social contexts [11]. In addition, results show that study participants in the age group 33-50 years old compared to those 18-32 years old, appear to be fonder of cut flowers, as this age group purchases cut flowers more frequently, has higher expenditures, and perceives flowers also to enhance value when combined with other gifts, such as books, music, gift cards, candy, and wine [11]. In conclusion, fondness for cut flowers, understanding cut flowers, and believing that cut flowers are appropriate for a wide variety of messages and social contexts are likely to increase the preference for gifting cut flowers. Thus, the following additional hypotheses are proposed:

Hypothesis 5 (H5). German consumers' flower fondness positively impacts their cut flower gift preferences.

Hypothesis 6 (H6). German consumers' subjective cut flower knowledge positively impacts their cut flower gift preferences.

Hypothesis 7 (H7). German consumers' assessment of cut flower gift versatility positively impacts their cut flower gift preferences.

\subsection{Socio-Demographic Background of Flower Buyers}

With respect to the socio-demographics of plant and flower buyers, Gabriel and Menrad (2013) provide some insights [43]. Their cluster analysis identified three major plant buyer groups in Southern Germany which can be distinguished by past buying behavior and socio-demographic characteristics, such as buying frequency, expenditures for horticultural products, gender, and age. Group one consists of three consumer clusters that prefer to buy in specialized flower shops and garden centers which are named as "Heavy Buyers in Traditional Retail Stores", "Traditional All-in-All Buyers", and "Apartment Greeners". "Heavy Buyers" appreciate advice when shopping, are interested in horticultural events, and have above average incomes (2600 Euro). "All-in-All Buyers" have above average income, make weekly purchases, and are predominantly female. "Apartment Greeners" are fans of potted plants, in particular bed and balcony plants, they request personal advice when shopping, and are mostly sixty or older. The expenditures for these three clusters range from 227 Euro (sample average) per year to 547 Euro per year.

"Event Buyers" and "Garden Builders" belong to the second group who prefer buying horticultural products in non-specialist distribution channels (such as supermarkets or home improvement stores) and have below average annual plant expenses. While the "Event Buyers" are mainly interested in flowering plants and show high interest in special offers and promotion activities, the "Garden Builder" is more interested in outdoor plants. Buyers in these groups are mostly younger than 50 years old and have average or above average incomes.

The third group of customers consists of "Low Interest Consumers", "Rare Buyer", and "Men's Domain". These clusters have a rather low interest in plants or flowers resulting in low purchase frequencies for horticultural products. Purchases are made for specific occasions, for instance gifts; therefore, expenses on these occasions are high. This group is not interested in advertisements, events, discounts, or offers. 
Schoeps et al. (2008) emphasized young families as frequent buyers of flowers and ornamental plants. Their survey work shows that people in this consumer group have high net household incomes and are often under-represented in horticultural studies, even though they are in a promising consumer group because their children's prospective consumption behavior is based on their influence [44].

Schettler et al. (2016) confirmed some of Gabriel and Menard's findings [20,43]. Their focus groups with online and brick and mortar cut flower buyers in Germany show that men under 30 have very little interest in plants and cut flowers. Regardless of gender and age, most consumers reported to purchase from online stores only for gift purchases [20]. US studies such as Rihn et al. (2011) found that "Generation X and Y" Michigan residents have diverse attitudes and flower preferences. While the "Generation X" participants were floral fans, some of the "Generation Y" consumers disapproved of floral products because they were not trendy, or because of their relative high cost, their lack of appropriateness, and lack of uniqueness [11]. In contrast, Schimmenti et al. (2013) found that Italian consumers perceive cut flowers as a very appropriate gift, especially for special occasions. While potted plant purchases were linked to personal use, the study found that women seem to be interested in gifting cut flower purchases [11,42].

In summary, there is a recent body of literature that suggests the importance of sociodemographic characteristics as a determinant of flower and floral gift purchases, but there is little consensus in their conclusions $[11,43,44]$. It is possible that socio-demographics have been used to predict floral gift purchases because experiential and attitudinal constructs have not been measured. The inclusion of experiential, attitudinal, and socio-demographic characteristics in a single model could uncover their relative predictive power of cut flower gift preferences. While there seems to be consensus that age, income, and education positively impact flower gift preference, it seems that gender may alter the experiential and attitudinal factors and perhaps their relationships. Thus, the following hypotheses and an exploratory research question are proposed:

Hypothesis 8a (H8a). German consumers' age positively impacts their cut flower gift preferences.

Hypothesis $\mathbf{8 b} \mathbf{( H 8 b )}$. German consumers' income positively impacts their cut flower gift preferences.

Hypothesis 8c (H8c). German consumers' education positively impacts their cut flower gift preferences.

Exploratory Research Question (ERQ). Do the hypothesized relationships found in the overall sample apply to males and females?

\subsection{Conceptual Model}

A conceptual model is proposed (Figure 1) suggesting that consumer preferences for cut flowers as a gift are the result of a combination of engagement, attitudes, and knowledge, and these individual experiential and attitudinal predictors are pitted against the more traditional socio-demographic predictors. Essentially, the experiential/attitudinal part of the model proposes that customers who engage with plants and nature are more likely to know more about cut flowers and have a fondness for them. Higher flower fondness, knowledge, and a strong belief that flowers are a versatile gift are likely to lead to a preference for cut flowers as a gift. The socio-demographic part of the model suggests that age, income, and education influence cut flower preferences, and ERQ1 is examined by testing the model with male and female sub-samples. 

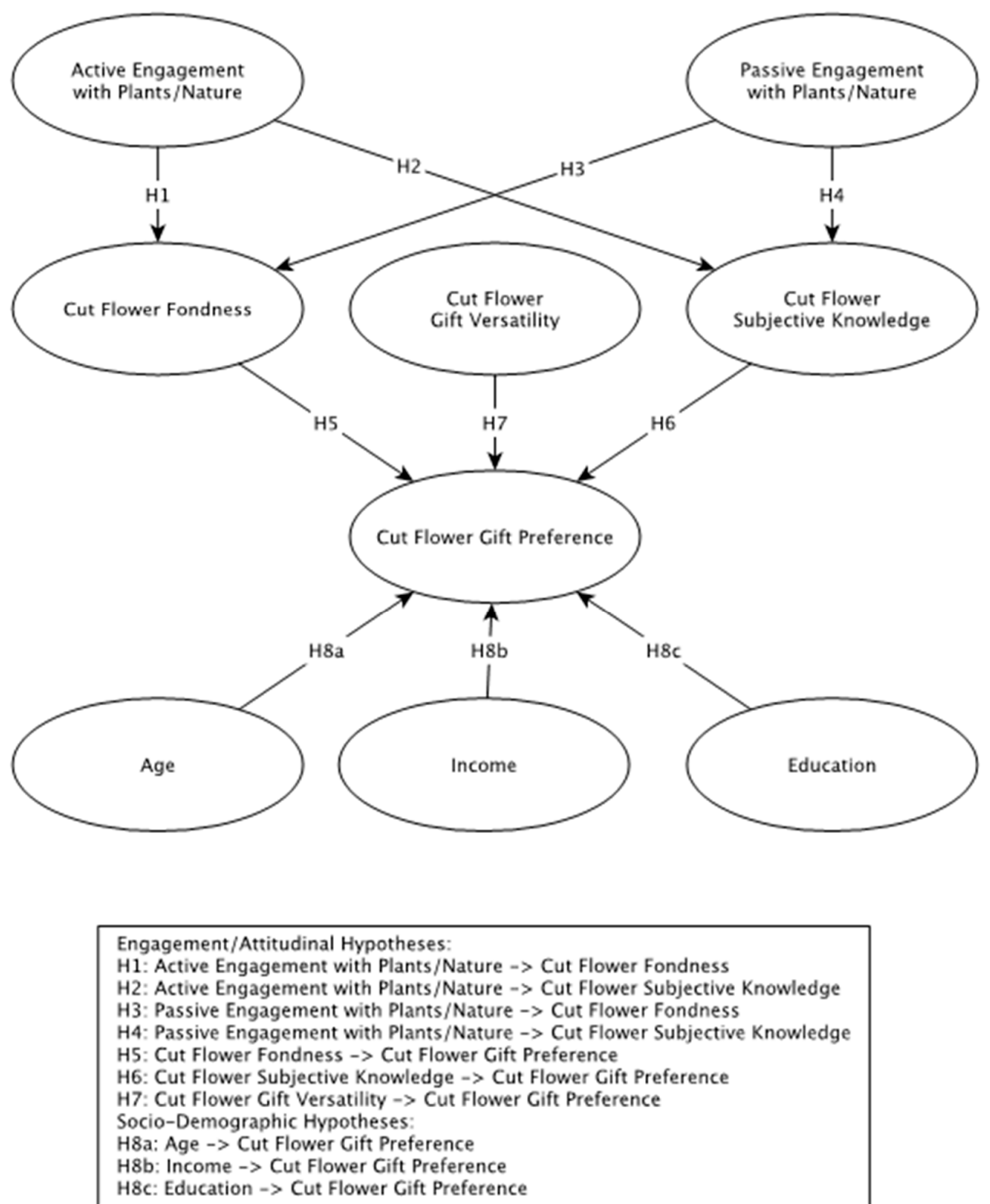

Figure 1. Conceptual Framework.

\section{Materials and Methods}

\subsection{Survey Instrument and Data Collection}

Data were gathered from a sample of German residents targeted to be representative of the German population in terms of age, gender, monthly net household income, federal state as specified by the most recent German census (2011), and the federal income and expenditure survey (2013) [45]. Gender, net household income, and geographical distribution in the sample were within $1 \%$ of census frequencies. We focused on a representative sample of German citizens being of legal age as flowers can be bought across all strata. Even though minors can purchase flowers, they were excluded from the sample. Minors fall into a protected class of people and by German law, minors cannot give consent for themselves. Gaining consent for their participation in the survey proved to be problematic, particularly in online questionnaire administration.

A questionnaire was developed for an online survey that was administered in March 2016. Online surveys are a standard data collection instrument because of their fast completion rates, low costs, and this survey form not showing nonresponse bias [46-48]. The 
survey was hosted via Qualtrics, and distributed via email by Lightspeed GMI, a company managing opt-panels. Respondents had to be German residents and 18 years old to participate. The data collection resulted in 978 completed responses which were analyzed.

The necessary survey sample size $(S)$ was calculated as $s=x /[1+(x / P)]$. In this equation, $\mathrm{P}$ is the total size of the population (82.18 million people) from which the sample is drawn and $x=Z \times Z\{[F \times(1-F)] /(D \times D)\}$, in which $Z$ is the area under the normal curve corresponding to the desired confidence level (1.96, per a 95\% confidence interval), $\mathrm{F}$ is the frequency of the factor in the study (0.5), and D is the maximum acceptable difference between the sample and population means (0.05). Consequently, the sample of 978 German residents who completed the survey is sufficient to determine German residents' engagement with nature, knowledge about and interest in cut flowers, and their preferences for floral gifts, and is well above minimum sample size to be analyzed using partial least squares structural equation modelling (PLS-SEM) [49]. The questionnaire was written in the German language and prior to data collection was pre-tested by 10 academics.

Two methods were employed to analyze the data. First, descriptive analyses were performed, using SPSS, to statistically describe the sample, and provide summary statistics of the variables measured. Next, PLS-SEM was employed, using SmartPLS to examine the research model and test the proposed hypotheses. PLS-SEM was employed due to its suitability for examining structural models and coefficient paths where data are not normally distributed [49]. To test the hypotheses and evaluate the structural model, Hair et al.'s (2017) recommendations were followed, and a bootstrapping method with 5000 iterations was employed [49]. Prior to assessing the proposed model and hypotheses, reliability and validity checks were conducted via measurement model functions in SmartPLS.

\subsection{Data Analysis}

Table 1 shows the frequencies for the demographics and the two constructs that were measured with single items. The frequencies are reported for the overall sample and by gender. While there were some demographic variations across the genders, the single item constructs only showed small differences.

Table 1. Sample Description and Single Item Frequencies.

\begin{tabular}{|c|c|c|c|c|c|c|}
\hline \multirow[b]{2}{*}{ Age } & \multicolumn{2}{|c|}{ Overall } & \multicolumn{2}{|c|}{ Female } & \multicolumn{2}{|c|}{ Male } \\
\hline & Freq & $\%$ & Freq & $\%$ & Freq & $\%$ \\
\hline 18-29 years & 171 & 17.5 & 124 & 24.2 & 47 & 10.1 \\
\hline 30-49 years & 345 & 35.3 & 191 & 37.2 & 154 & 33.1 \\
\hline 50-64 years & 244 & 24.9 & 120 & 23.4 & 124 & 26.7 \\
\hline 65 years and above & 218 & 22.3 & 78 & 15.2 & 140 & 30.1 \\
\hline Total & 978 & 100 & 513 & 100 & 465 & 100 \\
\hline \multicolumn{7}{|c|}{ Education } \\
\hline No Professional Certificate & 44 & 4.5 & 26 & 5.1 & 18 & 3.9 \\
\hline Vocational Degree & 421 & 43 & 253 & 49.3 & 168 & 36.1 \\
\hline Technical Degree & 97 & 9.9 & 46 & 9 & 51 & 11 \\
\hline Professional Academy & 63 & 6.4 & 28 & 5.5 & 35 & 7.5 \\
\hline Applied Science Degree & 128 & 13.1 & 55 & 10.7 & 73 & 15.7 \\
\hline University Degree & 192 & 19.6 & 87 & 17 & 105 & 22.6 \\
\hline Doctoral degree & 18 & 1.8 & 8 & 1.6 & 10 & 2.2 \\
\hline Other & 15 & 1.5 & 10 & 1.9 & 5 & 1.1 \\
\hline Total & 978 & 100 & 513 & 100 & 465 & 100 \\
\hline
\end{tabular}


Table 1. Cont.

\begin{tabular}{|c|c|c|c|c|c|c|}
\hline \multirow[b]{2}{*}{ Age } & \multicolumn{2}{|c|}{ Overall } & \multicolumn{2}{|c|}{ Female } & \multicolumn{2}{|c|}{ Male } \\
\hline & Freq & $\%$ & Freq & $\%$ & Freq & $\%$ \\
\hline \multicolumn{7}{|c|}{ Household Monthly Income } \\
\hline Less than $900 €$ & 76 & 7.8 & 44 & 8.6 & 32 & 6.9 \\
\hline 900 to $1299 €$ & 95 & 9.7 & 62 & 12.1 & 33 & 7.1 \\
\hline 1300 to $1499 €$ & 58 & 5.9 & 39 & 7.6 & 19 & 4.1 \\
\hline 1500 to $1999 €$ & 151 & 15.4 & 70 & 13.6 & 81 & 17.4 \\
\hline 2000 to $2599 €$ & 178 & 18.2 & 95 & 18.5 & 83 & 17.8 \\
\hline 2600 to $3599 €$ & 190 & 19.4 & 89 & 17.3 & 101 & 21.7 \\
\hline 3600 to $4999 €$ & 152 & 15.5 & 78 & 15.2 & 74 & 15.9 \\
\hline 5000 or more $€$ & 78 & 8 & 36 & 7 & 42 & 9 \\
\hline Total & 978 & 100 & 513 & 100 & 465 & 100 \\
\hline \multicolumn{7}{|c|}{ Relative Preference for Cut Flowers as a Gift } \\
\hline 1st Choice & 22 & 2.2 & 7 & 1.4 & 15 & 3.2 \\
\hline 2nd Choice & 29 & 3 & 15 & 2.9 & 14 & 3 \\
\hline 3rd Choice & 95 & 9.7 & 57 & 11.1 & 38 & 8.2 \\
\hline 4th Choice & 184 & 18.8 & 99 & 19.3 & 85 & 18.3 \\
\hline 5th Choice & 209 & 21.4 & 110 & 21.4 & 99 & 21.3 \\
\hline 6th Choice & 176 & 18 & 96 & 18.7 & 80 & 17.2 \\
\hline 7th Choice & 115 & 11.8 & 64 & 12.5 & 51 & 11 \\
\hline 8th Choice & 148 & 15.1 & 65 & 12.7 & 83 & 17.8 \\
\hline Total & 978 & 100 & 513 & 100 & 465 & 100 \\
\hline \multicolumn{7}{|c|}{ Subjective (Self-Assessed) Knowledge about Cut Flowers } \\
\hline Very well founded & 17 & 1.7 & 11 & 2.1 & 6 & 1.3 \\
\hline Well founded & 72 & 7.4 & 41 & 8 & 31 & 6.7 \\
\hline Above average & 182 & 18.6 & 80 & 15.6 & 102 & 21.9 \\
\hline Average & 238 & 24.3 & 129 & 25.1 & 109 & 23.4 \\
\hline Below average & 165 & 16.9 & 93 & 18.1 & 72 & 15.5 \\
\hline Little & 160 & 16.4 & 77 & 15 & 83 & 17.8 \\
\hline Very little & 144 & 14.7 & 82 & 16 & 62 & 13.3 \\
\hline Total & 978 & 100 & 513 & 100 & 465 & 100 \\
\hline
\end{tabular}

\subsection{Measurement Model}

The assessment of the model's measurement was conducted to evaluate construct reliability and validity. Table 2 shows that all Cronbach Alpha and composite reliability indicators have values higher than 0.7 and the average variance extracted (AVE) have values of more than 0.5. Further, the factor loadings of all items are more than 0.6. With all indicators within acceptable ranges, the requirements of construct reliability and validity were deemed to have been satisfied [49].

Table 2. Scale Loadings, Reliabilities, and Convergent Validity.

\begin{tabular}{|c|c|c|c|c|}
\hline Scales and Items & $\begin{array}{c}\text { Factor } \\
\text { Loadings }\end{array}$ & $\begin{array}{c}\text { Cronbach's } \\
\text { Alpha }\end{array}$ & $\begin{array}{l}\text { Composite } \\
\text { Reliability }\end{array}$ & AVE \\
\hline Active Engagement with Plants/Nature & & 0.813 & 0.887 & 0.725 \\
\hline $\begin{array}{l}\text { 11.1 I enjoy collecting plants (herbaria, preservation } \\
\text { of varieties). }\end{array}$ & 0.815 & & & \\
\hline $\begin{array}{c}11.2 \text { I enjoy cultivation work (pulling weeds, mowing } \\
\text { the lawn). }\end{array}$ & 0.807 & & & \\
\hline $\begin{array}{l}\text { 11.7 I enjoy harvesting fruits and vegetables from } \\
\text { my garden. }\end{array}$ & 0.790 & & & \\
\hline 11.9 I enjoy cultivating an allotment garden. & 0.729 & & & \\
\hline Passive Engagement with Plants/Nature & & 0.798 & 0.866 & 0.618 \\
\hline 11.3 I enjoy decorating with plants and flowers. & 0.889 & & & \\
\hline 11.4 I enjoy sitting in the garden or on the balcony. & 0.762 & & & \\
\hline 11.6 I enjoy observing plants in the course of the seasons. & 0.896 & & & \\
\hline
\end{tabular}


Table 2. Cont.

\begin{tabular}{ccccc}
\hline Scales and Items & $\begin{array}{c}\text { Factor } \\
\text { Loadings }\end{array}$ & $\begin{array}{c}\text { Cronbach's } \\
\text { Alpha }\end{array}$ & $\begin{array}{c}\text { Composite } \\
\text { Reliability }\end{array}$ & AVE \\
\hline Cut Flower Fondness & & 0.706 & 0.828 & 0.616 \\
\hline 14.1 Cut flowers are a natural product. & 0.704 & & & \\
14.2 Cut flowers as an item of decoration. & 0.757 & & 0.905 & \\
14.3 Cut flowers bring back memories. & 0.854 & & & \\
\hline Cut Flower Gift Versatility & & & & \\
\hline 17.5 I give cut flowers to express affection. & 0.861 & & \\
17.6 I give cut flowers to apologize. & 0.739 & & & \\
17.8 I give cut flowers to express sympathy. & 0.849 & & & \\
17.12 I give cut flowers as a thank-you gift. & 0.881 & & & \\
\hline
\end{tabular}

The next step in the model's measurement is to check the discriminant validity of the constructs. The Fornell-Larcker criterion and heterotrait multitrait (HTMT) ratio were used to assess the discriminant validity of the model constructs. Table 3 shows that the discriminant validity requirements are met for all variable constructs as the square root of each construct's AVE is higher than its correlation with other constructs, and the HTMT ratios are all less than 0.90 [44].

Table 3. Fornell-Larcker Criterion and Heterotrait Multitrait Ratio.

\begin{tabular}{|c|c|c|c|c|c|c|}
\hline $\begin{array}{l}\text { Fornell-Larcker } \\
\text { Criterion }\end{array}$ & $\begin{array}{c}\text { Active } \\
\text { Engagement } \\
\text { with } \\
\text { Plants/Nature }\end{array}$ & $\begin{array}{l}\text { Cut Flower } \\
\text { Fondness }\end{array}$ & $\begin{array}{l}\text { Cut Flower } \\
\text { Subjective } \\
\text { Knowledge }\end{array}$ & $\begin{array}{c}\text { Cut Flower } \\
\text { Gift } \\
\text { Preference }\end{array}$ & $\begin{array}{c}\text { Cut Flower } \\
\text { Gift } \\
\text { Versatility }\end{array}$ & $\begin{array}{c}\text { Passive } \\
\text { Engage- } \\
\text { ment with } \\
\text { Plants/Nature }\end{array}$ \\
\hline $\begin{array}{l}\text { Active Engagement } \\
\text { with Plants/Nature }\end{array}$ & 0.786 & & & & & \\
\hline Cut Flower Fondness & 0.295 & 0.785 & & & & \\
\hline $\begin{array}{c}\text { Cut Flower Subjective } \\
\text { Knowledge }\end{array}$ & 0.465 & 0.313 & 1.000 & & & \\
\hline $\begin{array}{l}\text { Cut Flower Gift } \\
\text { Preference }\end{array}$ & 0.211 & 0.332 & 0.205 & 1.000 & & \\
\hline $\begin{array}{l}\text { Cut Flower Gift } \\
\text { Versatility }\end{array}$ & 0.322 & 0.549 & 0.326 & 0.435 & 0.839 & \\
\hline $\begin{array}{l}\text { Passive Engagement } \\
\text { with Plants/Nature }\end{array}$ & 0.587 & 0.500 & 0.372 & 0.253 & 0.437 & 0.851 \\
\hline \multicolumn{7}{|l|}{$\begin{array}{c}\text { Heterotrait-Monotrait } \\
\text { Ratio }\end{array}$} \\
\hline Cut Flower Fondness & 0.350 & & & & & \\
\hline $\begin{array}{c}\text { Cut Flower Subjective } \\
\text { Knowledge }\end{array}$ & 0.508 & 0.333 & & & & \\
\hline $\begin{array}{l}\text { Cut Flower Gift } \\
\text { Preference }\end{array}$ & 0.226 & 0.372 & 0.205 & & & \\
\hline $\begin{array}{l}\text { Cut Flower Gift } \\
\text { Versatility }\end{array}$ & 0.387 & 0.664 & 0.359 & 0.459 & & \\
\hline $\begin{array}{l}\text { Passive Engagement } \\
\text { with Plants/Nature }\end{array}$ & 0.696 & 0.618 & 0.390 & 0.264 & 0.499 & \\
\hline
\end{tabular}

\subsection{Structural Model}

The proposed structural model was tested resulting in a normal fit index of 0.776 and a standardized root mean square residual of 0.068 for the overall sample, with 0.069 for the female sub-sample, and 0.075 for the male sub-sample. All were less than Hair et al. (2017)'s recommended maximum of 0.08 , indicating adequate model fit [49]. Next, the explanatory power of the model was examined, and the model constructs of cut flower fondness, cut flower subjective knowledge, gift purpose specificity, and demographics (age, education, and income) contributed to an $R^{2}$ for a cut flower gift preference of 0.210 (overall), 0.187 (females), and 0.245 (males). This indicates that $21 \%$ of the cut flower gift preference could be explained with those constructs. Other model structure tests were performed including path coefficient averages and collinearity. The path coefficient average check resulted in the value of 0.166 (overall), 0.160 (females) and 0.187 (males); all significant at $p<0.01$. Further, collinearity among the constructs was checked using the averaged variance inflation factor (VIF) score, which was 1.349, and under the maximum recommended level of 5 [49]. 


\section{Results}

The results of the hypotheses tests (Table 4) show that the association between active engagement and cut flower fondness was not significant, indicating no support for hypothesis $\mathrm{H} 1$ in the overall, female, or male samples. The relationships between active engagement and cut flower knowledge, passive engagement and cut flower fondness, and between passive engagement and cut flower knowledge were significant $(p<0.05)$ for all three samples, indicating support for H2, H3, and H4. There was support for H5, as the relationship between cut flower knowledge and cut flower gift preference $(p<0.01)$, but only for the overall and female sample. Conversely, support was found for H6 as the relationship between cut flower knowledge and cut flower gift preference $(p<0.05)$ but only for the male sample. Full support was found for $\mathrm{H} 7$ as the relationship between gift purpose specificity and cut flower gift preference was significant $(p<0.01)$ for all three samples. Support was found for H8a as age was found to be related to cut flower gift preference $(p<0.01)$, but only in the overall sample. No support was found for H8b or H8c as income and education were not found to be related to cut flower preference. Regarding ERP1, the conceptual model was confirmed for the sample and the gender sub-samples, but there seemed to be some differences in the role of cut flower fondness $(\mathrm{H} 5)$ and cut flower subjective knowledge (H6) between the genders. While not hypothesized, the path coefficients indicate statistical importance so larger path coefficients could be viewed as more important or more influential. It is noteworthy that for cut flower fondness, passive engagement was the most influential for males and females and for cut flower subjective knowledge, active engagement was the most influential for males and females. In addition, for cut flower gift preference, cut flower versatility was the most influential for males and females.

Table 4. Path Coefficient Results.

\begin{tabular}{|c|c|c|c|c|c|c|}
\hline \multirow[b]{2}{*}{ Engagement/Attitudinal Hypotheses: } & \multicolumn{2}{|c|}{ Overall } & \multicolumn{2}{|c|}{ Females } & \multicolumn{2}{|c|}{ Males } \\
\hline & Beta & $p$-Value & Beta & $p$-Value & Beta & $p$-Value \\
\hline $\begin{array}{c}\text { H1: Active Engagement with } \\
\text { Plants / Nature -> Cut Flower Fondness } \\
\text { H2: Active Engagement with }\end{array}$ & 0.002 & 0.948 & -0.051 & 0.299 & 0.047 & 0.353 \\
\hline $\begin{array}{c}\text { Plants/Nature -> Cut Flower Subjective } \\
\text { Knowledge }\end{array}$ & 0.376 & 0.000 & 0.358 & 0.000 & 0.366 & 0.000 \\
\hline $\begin{array}{l}\text { H3: Passive Engagement with } \\
\text { Plants/Nature -> Cut Flower Fondness } \\
\text { H4: Passive Engagement with }\end{array}$ & 0.499 & 0.000 & 0.469 & 0.000 & 0.531 & 0.000 \\
\hline $\begin{array}{c}\text { Plants/Nature -> Cut Flower Subjective } \\
\text { Knowledge }\end{array}$ & 0.151 & 0.000 & 0.107 & 0.021 & 0.246 & 0.000 \\
\hline $\begin{array}{l}\text { H5: Cut Flower Fondness -> Cut Flower } \\
\text { Gift Preference }\end{array}$ & 0.118 & 0.002 & 0.167 & 0.001 & 0.063 & 0.273 \\
\hline $\begin{array}{l}\text { H6: Cut Flower Subjective Knowledge -> } \\
\text { Cut Flower Gift Preference }\end{array}$ & 0.053 & 0.075 & 0.016 & 0.701 & 0.092 & 0.028 \\
\hline $\begin{array}{l}\text { H7: Cut Flower Gift Versatility -> Cut } \\
\text { Flower Gift Preference }\end{array}$ & 0.360 & 0.000 & 0.314 & 0.000 & 0.410 & 0.000 \\
\hline \multicolumn{7}{|l|}{ Demographic Hypotheses: } \\
\hline H8a: Age -> Cut Flower Gift Preference & -0.071 & 0.012 & -0.070 & 0.080 & -0.058 & 0.164 \\
\hline $\begin{array}{c}\text { H8b: Income -> Cut Flower Gift } \\
\text { Preference }\end{array}$ & -0.017 & 0.569 & -0.007 & 0.862 & -0.033 & 0.415 \\
\hline $\begin{array}{c}\text { H8c: Education -> Cut Flower Gift } \\
\text { Preference }\end{array}$ & -0.009 & 0.755 & -0.043 & 0.332 & 0.021 & 0.611 \\
\hline
\end{tabular}

bold $=$ significant.

The graphical summary of the relationships between the variables tested on male and female sub-groups is depicted in Figure 2. 


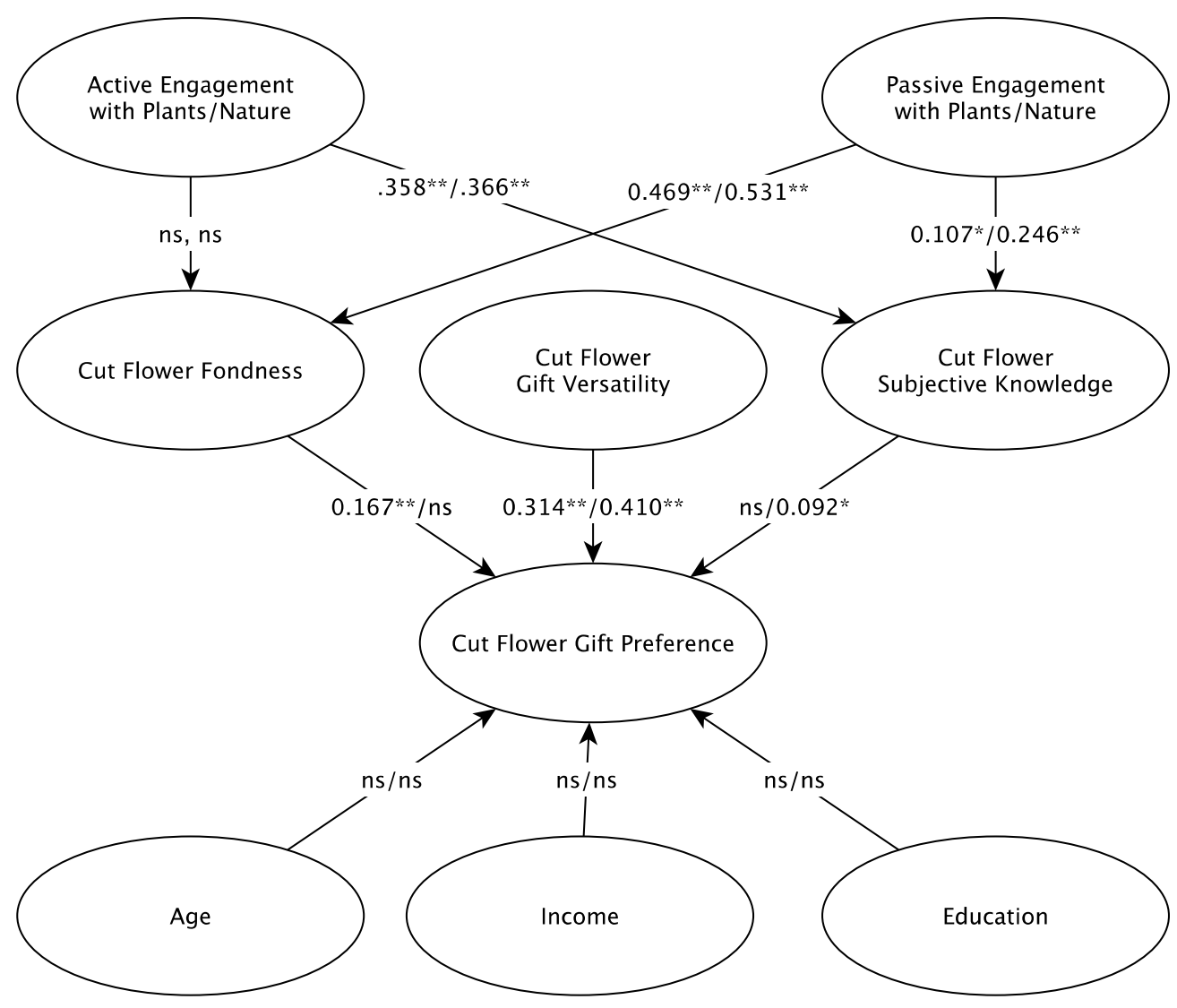

Figure 2. Conceptual framework including relationships between the variables tested on male and female sub-groups. Notes: ${ }^{*}$ Significant at $p<0.05 ;{ }^{* *}$ Significant at $p<0.01$; ns: not significant; Results: female/male.

\section{Discussion}

This study seeks to contribute to the understanding of the impact of experience, attitudes, and demographics on cut flower gifting preferences amongst German consumers. More precisely it explores new and existing factors such as socio-demographic information, cut flower gift versatility, and cut flower fondness, and tests whether they are associated with cut flower gifting preferences in Germany. Active engagement with nature and plants, as well as subjective flower knowledge, have been developed alongside the existing factors.

Overall, the proposed cut flower gifting preference model is found to have adequate fit and explanatory power. The model confirms previous findings that cut flower gift versatility is one of the main drivers for cut flower preferences $[11,50]$. Further, the results endorse the notion that cut flower fondness is a driver for cut flower gift preferences for women $[11,20,43]$. This suggests that the beautification, sentiment, and emotional value of cut flowers are important for German women when choosing cut flowers as a gift. Getting the right gift and sending the right message is essential given the flower fondness of German women in the context of cut flower preferences as suggested by the proposed model. This information is valuable for florists and German flowers marketers when developing strategies for new or existing floral product offerings.

Cut flower fondness is positively impacted by higher passive engagement with plants and nature, which is unsurprising because passive plant activities such as sitting on the balcony or observing plants throughout the course of the season are closely aligned with the purpose and nature of cut flowers. Those who are passively engaged with nature enjoy surrounding themselves with plants and flowers, so they are likely to appreciate cut flowers as a natural product, view them as decorative items, and have fond memories involving flowers. Scent and color are likely to be important product attributes for buyers who 
passively engage with nature. Both attributes contribute to sensory stimulation whether in a home environment decorated with cut flowers or observing and enjoying plants and flowers in the garden.

Similarly, as the seasons change, cut flowers change their physical appearance and scent, which include often attractive color variations, the development of petals, and the visibility of reproductive plant structures from buds to full blooms. This finding is consistent with Yue and Behe (2010) who outline the importance of consumers' preferences for cut flower colors according to the season [43]. Active engagement with plants and nature, such as cultivation, gardening, and harvesting, did not translate into higher cut flower fondness but did increase knowledge. Perhaps these activities have chore-like qualities and are not as likely to endear one to flowers the way that sitting in the garden, observing, and enjoying might. Yet, they provide insight into elementary plant production and maintenance experience; therefore, they might have impacted the results in terms of subjective cut flower knowledge. Overall, the results of passive and active engagement confirm findings of various studies in environmental psychology which focus on environmental attitudes and nature as an attitudinal object. Following Bruegger (2011) and Kaiser et al. (2013), people who are connected in various ways to nature appreciate outdoor activities, the environment, and their relationship with nature [51,52].

For German men, cut flower versatility is the primary influence driving their flower gift preferences, cut flower knowledge is a secondary influence, and no influence is found for flower fondness. With the absence of flower fondness as a driver, perhaps German men rely on their understanding or familiarity with cut flowers as a gift, especially when compared to other gift items. Cut flowers are a safe, traditional, and appropriate gift in German culture [21]. Alternative gifts such as candles, books, gift certificates, and photo frames, may be less understood or may not have the same versatility and could potentially lead to unintended or confusing messages for the receiver. At the very least, the differing paths between the female and male sub-samples indicate that gender plays an important role in the relationships between attitudes and purchasing preferences of cut flower gifts.

The other socio-demographic characteristics, such as age, income, and education, do not appear to be significant factors impacting German consumers' cut flower gift preferences. One explanation is that when modelled with experiential and attitudinal variables, their influence is subsumed. Another explanation is that their lack of influence is an artifact of the German sample. The majority of previous studies stem from other cultural contexts for instance the U.S. or Italy $[11,43,50]$, or German studies $[20,43,44]$ with less representative samples than the present study. The existing German studies were often convenience or purposive samples focusing on Bavarian and South German consumers.

Notwithstanding, the present study supports the findings of Schreiner et al. (2013), outlining what consumers perceive as flower quality [25]. In gift giving situations, consumers are likely to prefer high quality products due to the reciprocal nature, the asymmetric relationship between giver and recipient, and the underlying message to be transferred. Schreiner et al. (2013) indicated that lifestyle, social milieus, and values are more important factors than socio-demographic information in the context of floral preferences and quality [5].

\section{Managerial Implications}

The previously discussed results are of relevance to German florists and marketing managers, who can use the information to improve flower advertisements to increase the demand for floral gifts and cut flowers. Marketing strategies for cut flower gifts could emphasize product versatility and facts about the specific flowers and their production. This may help to attract a wider audience to cut flowers, those being fond of the products and others alike. Following Rombach et al. (2018a), who proposed "sensory corners" in physical flower retail as sensory stimulating locations where flower bouquets are on display and where consumers are invited to rest and read about flowers, to increase their 
interest in cut flowers and floral gifts, could be translated into "online corners" [19]. This may help to facilitate safe and contactless cut flower shopping in 2021.

To target German men, florists and marketers may avoid assuming a male fondness for flowers and offer messages that highlight the versatility of flowers as gifts, and how the various cut flower products (e.g., bouquets, single stems, floral wreath, flower clip, garland) can deliver a variety of messages in a number of social situations. Sharing this type of knowledge may be the most effective strategy to encourage cut flower gifting from those who do not already have a fondness for them.

Furthermore, public and commercial holidays that typically generate a high demand for flowers, for instance Valentine's Day and Mother's Day, may serve as an opportunity for education and communication campaigns for floral gifts and cut flowers. Florists can use the metaphors of "seasons change" to advertise seasonal varieties and colors and enhance consumer education on flower-related topics like how to prolong vase life. Such campaigns could strive to increase the use of cut flowers as gifts. Alert levels of the COVID19 pandemic impact the daily life of consumers and flower businesses alike. Aligned with cut flower versatility, the various sentiments of love and care that can be communicated through cut flowers have the potential to temper hardship and increase wellbeing among the German public while keeping horticultural enterprises and florists in business.

\section{Limitations and Suggestions for Future Research}

The data for the present study are from 2016; given the significant changes in spending behaviors and consumer attitudes due to COVID-19 disruptions, the precise purchasing patterns have likely changed. However, given the conceptual framework of the model and the relatively small number of ornamental flower studies in Germany, it is felt that the research in its current form still adds value to the existing body of literature, as well as to consultants and industry actors.

In future research, the model could be applied to representative samples from other countries to better understand cultural differences in cut flower gift giving preferences and shed light onto the discrepancies related to socio-demographic information. Further, the approach could be applied to potted plants, as it is likely that consumers consider different gift versatilities and contexts appropriate [53,54]. Further studies could investigate the willingness to pay, or cut flower attribute preferences for floral gifts of young consumers in various online shopping scenarios, or of herbs and edible flowers which are increasing in popularity $[55,56]$.

Due to the COVID-19 pandemic and the increased importance of contactless payment, an online context would be recommended for further explanation. The design for giving scenarios can follow the proposed outline in the present study, as well as Rihn et al. (2011), if flowers are given as an addition to a different gift item [11]. Given the devastating nature of COVID-19, models devoted to sympathy scenarios could be explored, potentially advising florists on how to promote appropriate floral gifts in delicate situations and uncertain times. A gift giving scenario in a sympathy context would certainly fill an unexplored research gap for German consumers.

Supplementary Materials: The following are available online at https:/ /www.mdpi.com/article/10 .3390/horticulturae7100368/s1, Table S1: Most popular flowers in Germany, Figure S1: Example of a flower bouquet sold in physical retail in Germany, Figure S2: Example of a flower bouquet sold in a discounter in Germany.

Author Contributions: Conceptualization, M.R. and D.L.D.; methodology, D.L.D.; validation, M.R., D.L.D., N.J.O.W., V.B.; formal analysis, D.L.D.; investigation, M.R., N.J.O.W., V.B.; resources, M.R., V.B., D.L.D., N.J.O.W.; data curation, D.L.D.; writing—original draft preparation, M.R. and D.L.D.; writing-review and editing, D.L.D., N.J.O.W., V.B., M.R.; visualization, D.L.D.; project administration, M.R., V.B., N.J.O.W. All authors have read and agreed to the published version of the manuscript.

Funding: No specific funding has been attributed to the project. 
Data Availability Statement: The data presented in this study are available on request from the corresponding author.

Acknowledgments: The authors wish to express their gratitude to Luke W. Tepid for his refreshing advice on the topic matter and Cora Huhn for her assistance with the flower photography.

Conflicts of Interest: The authors declare no conflict of interest in the context of this publication. The funders had no role in the design of the study; in the collection, analyses, or interpretation of data; in the writing of the manuscript or in the decision to publish the results.

Ethical Statement: All participants gave their informed consent for inclusion before they participated in the study. The study was conducted in accordance with the Declaration of Helsinki, and the protocol was approved by the Institutional Review Board of Purdue University in November 2015.

\section{References}

1. Mortimer, G.; Bougoure, U.S.; Fazal-E-Hasan, S. Development and validation of the Self-Gifting Consumer Behaviour scale. J. Consum. Behav. 2015, 14, 165-179. [CrossRef]

2. Sherry, J.F., Jr. Gift giving in anthropological perspective. J. Consum. Res. 1983, 10, 157-168. [CrossRef]

3. Minowa, Y.; Belk, R.W. (Eds.) Gifts, Romance, and Consumer Culture; Routledge: New York, NY, USA, 2018.

4. Steidlmeier, P. Gift Giving, Bribery and Corruption: Ethical Management of Business Relationships in China. J. Bus. Ethics 1999, 20, 121-132. [CrossRef]

5. Belk, R.W.; Wallendorf, M.; Sherry, J.J.F. The Sacred and the Profane in Consumer Behavior: Theodicy on the Odyssey. J. Consum. Res. 1989, 16, 1-38. [CrossRef]

6. Hutter, K.; Hoffmann, S. Surprise, Surprise. Ambient Media as Promotion Tool for Retailers. J. Retail. 2014, 90, 93-110. [CrossRef]

7. Heath, T.P.; Tynan, C.; Ennew, C. Accounts of self-gift giving: Nature, context and emotions. Eur. J. Mark. 2015, 49, 1067-1086. [CrossRef]

8. Hwang, J.; Chu, W. The effect of others' outcome valence on spontaneous gift giving behavior: The role of empathy and self-esteem. Eur. J. Mark. 2019, 53, 785-805. [CrossRef]

9. Joy, A. Gift Giving in Hong Kong and the Continuum of Social Ties. J. Consum. Res. 2001, 28, 239-256. [CrossRef]

10. Lai, Y.-C.; Huang, L.-C. The Effect of Relationship Characteristics on Buying Fresh Flowers as Romantic Valentine's Day Gifts. HortTechnology 2013, 23, 28-37. [CrossRef]

11. Rihn, A.L.; Yue, C.; Behe, B.; Hall, C. Generations X and Y Attitudes toward Fresh Flowers as Gifts: Implications for the Floral Industry. HortScience 2011, 46, 736-743. [CrossRef]

12. Huang, L.-C.; Lin, Y.-C. Who Decides to Give a Gift of Fresh Flowers? The Effects of Givers and Receivers on the Likelihood of Buying Fresh Flowers for Gifts. HortScience 2015, 50, 1028-1034. [CrossRef]

13. Yue, C.; Hall, C. Traditional or Specialty Cut Flowers? Estimating U.S. Consumers' Choice of Cut Flowers at Noncalendar Occasions. HortScience 2010, 45, 382-386. [CrossRef]

14. Belk, R.W.; Coon, G.S. Gift Giving as Agapic Love: An Alternative to the Exchange Paradigm Based on Dating Experiences. J. Consum. Res. 1993, 20, 393-417. [CrossRef]

15. Larsen, D.; Watson, J.J. A guide map to the terrain of gift value. Psychol. Mark. 2001, 18, 889-906. [CrossRef]

16. Moreau, C.P.; Bonney, L.; Herd, K.B. It's the thought (and the effort) that counts: How customizing for others differs from customizing for oneself. J. Mark. 2011, 75, 120-133. [CrossRef]

17. Oppenheim, P.P. Understanding the factors influencing consumer choice of cut flowers: A means-end approach. Acta Hortic. 1996, 429, 415-422. [CrossRef]

18. Gabriel, A.; Menrad, K. Price perception and long-term price knowledge of buyers of ornamental plants. In Proceedings of the 2nd Symposium on Horticulture in Europe, Angers, France, 1-5 July 2012; pp. 139-140.

19. Rombach, M.; Widmar, N.; Byrd, E.; Bitsch, V. Understanding preferences of German flower consumers: The desire for sustained beauty. Int. J. Retail. Distrib. Manag. 2018, 46, 560-576. [CrossRef]

20. Schettler, C.; Rombach, M.; Bitsch, V. Perceived advantages and barriers of buying cut flowers online. Acta Hortic. 2016, 1132, 9-16. [CrossRef]

21. Berki-Kiss, D.; Menrad, K. Consumer Preferences of Sustainability Labeled Cut Roses in Germany. Sustainability 2019, 11, 3358. [CrossRef]

22. Rombach, M.; Widmar, N.O.; Byrd, E.; Bitsch, V. Do all roses smell equally sweet? Willingness to pay for flower attributes in specialized retail settings by German consumers. J. Retail. Consum. Serv. 2018, 40, 91-99. [CrossRef]

23. Rihn, A.L.; Yue, C.; Hall, C.; Behe, B.K. Consumer Preferences for Longevity Information and Guarantees on Cut Flower Arrangements. HortScience 2014, 49, 769-778. [CrossRef]

24. Rombach, M.; Bitsch, V. A typology of online flower shops on the German market. Acta Hortic. 2016, 1132, 127-134. [CrossRef]

25. Schreiner, M.; Korn, M.; Stenger, M.; Holzgreve, L.; Altmann, M. Current understanding and use of quality characteristics of horticulture products. Sci. Hortic. 2013, 163, 63-69. [CrossRef] 
26. BMEL. Performance Report Horticulture and Viticulture. In German: Ertragslage Gartenbau und Weinbau. 2021. Available online: https:/ / www.bmel-statistik.de/landwirtschaft/gartenbau/veroeffentlichungen-zum-gartenbau/ertragslage-gartenund-weinbau/ (accessed on 11 August 2021).

27. Lampert, P.; Menrad, K.; Schoeps, J. Consumer attitudes for new plant species using the example of Trachycarpus wagnerianus. J. Hortic. For. 2012, 4, 129-135. [CrossRef]

28. Bermejo, G.; Sparke, K. Happier in a home with plants? A study on the relationship between human wellbeing and ornamental plants in private households. Acta Hortic. 2019, 47-54. [CrossRef]

29. Dominguez, G.B.; Mibus-Schoppe, H.; Sparke, K. Evaluation of existing research concerning sustainability in the value chain of ornamental plants. Eur. J. Sustain. Dev. 2017, 6, 11-19. [CrossRef]

30. Paiva, P.D.D.O.; Dos Reis, M.V.; Sant'Ana, G.S.; Bonifácio, F.D.L.; Guimarães, P.H.S. Flower and ornamental plant consumers profile and behavior. Ornam. Hortic. 2020, 26, 333-345. [CrossRef]

31. Khachatryan, H.; Rihn, A.; Behe, B.; Hall, C.; Campbell, B.; Dennis, J.; Yue, C. Visual attention, buying impulsiveness, and consumer behavior. Mark. Lett. 2018, 29, 23-35. [CrossRef]

32. Khachatryan, H.; Rihn, A.; Hansen, G.; Clem, T. Landscape Aesthetics and Maintenance Perceptions: Assessing the Relationship between Homeowners' Visual Attention and Landscape Care Knowledge. Land Use Policy 2020, 95, 104645. [CrossRef]

33. Rihn, A.; Khachatryan, H.; Campbell, B.; Hall, C.; Behe, B. Consumer Response to Novel Indoor Foliage Plant Attributes: Evidence from a Conjoint Experiment and Gaze Analysis. HortScience 2015, 50, 1524-1530. [CrossRef]

34. Mckendree, M.G.S.; Croney, C.C.; Widmar, N.J.O. Bioethics Symposium II: Current factors influencing perceptions of animals and their welfare1. J. Anim. Sci. 2014, 92, 1821-1831. [CrossRef]

35. Cummins, A.M.; Widmar, N.J.O.; Croney, C.C.; Fulton, J.R. Exploring Agritourism Experience and Perceptions of Pork Production. Agric. Sci. 2016, 07, 239-249. [CrossRef]

36. Byrd, E.; Lee, J.G.; Widmar, N.J.O. Perceptions of Hunting and Hunters by U.S. Respondents. Animals 2017, 7, 83. [CrossRef] [PubMed]

37. Byrd, E.; Widmar, N.O.; Fulton, J. Of Fur, Feather, and Fin: Human's Use and Concern for Non-Human Species. Animals 2017, 7, 22. [CrossRef] [PubMed]

38. Heise, H.; Theuvsen, L. Consumers' willingness to pay for milk, eggs and meat from animal welfare programs: A representative study. J. Consum. Prot. Food Saf. 2017, 12, 105-113. [CrossRef]

39. Dahlhausen, J.L.; Rungie, C.; Roosen, J. Value of labeling credence attributes-common structures and individual preferences. Agric. Econ. 2018, 49, 741-751. [CrossRef]

40. Gross, S.; Waldrop, M.E.; Roosen, J. How does animal welfare taste? Combining sensory and choice experiments to evaluate willingness to pay for animal welfare pork. Food Qual. Prefer. 2021, 87, 104055. [CrossRef]

41. Schimmenti, E.; Galati, A.; Borsellino, V.; Ievoli, C.; Lupi, C.; Tinervia, S. Behaviour of consumers of conventional andorganic flowers and ornamental plants in Italy. Hortic. Sci. 2013, 40, 162-171. [CrossRef]

42. Yue, C.; Behe, B.K. Consumer Color Preferences for Single-stem Cut Flowers on Calendar Holidays and Noncalendar Occasions. HortScience 2010, 45, 78-82. [CrossRef]

43. Gabriel, A.; Menrad, K. Segmentation of customers of horticultural non-food products in Southern Germany. Ger. J. Agric. Econ. 2013, 62, 192-202.

44. Schöps, J.; Gabriel, A.; Menrad, K. Young families as buyers of horticultural products. Acta Hortic. 2009, 817, 285-292. [CrossRef]

45. German Census. Census Data Base of the Census 2011. 2011. Available online: https://ergebnisse.zensus2011.de/?locale=e (accessed on 5 September 2021).

46. Hudson, D.; Seah, L.-H.; Hite, D.; Haab, T. Telephone presurveys, self-selection, and non-response bias to mail and Internet surveys in economic research. Appl. Econ. Lett. 2004, 11, 237-240. [CrossRef]

47. Olynk, N.J.; Ortega, D.L. Consumer preferences for verified dairy cattle management practices in processed dairy products. Food Control 2013, 30, 298-305. [CrossRef]

48. Olynk, N.J.; Tonsor, G.T.; Wolf, C.A. Consumer willingness to pay for livestock credence attribute claim verification. J. Agric. Resour. Econ. 2010, 35, 261-280.

49. Hair, J.E.; Hult, G.T.; Ringle, C.M.; Sarstedt, M. A Primer on Partial Least Squares Structural Equation Modeling (PLS-SEM), 2nd ed.; Sage Publications: Los Angeles, CA, USA, 2017.

50. Yue, C.; Behe, B.K. Estimating U.S. Consumers' Choice of Floral Retail Outlets. HortScience 2008, 43, 764-769. [CrossRef]

51. Brügger, F.G.; Kaiser, N. Roczen. One for all? Eur. Psychol. 2011, 16, 324-333. [CrossRef]

52. Brügger, A.; Hartig, T.; Duvier, C.; Kaiser, F.G. Environmental protection and nature as distinct attitudinal objects: An application of the Campbell Paradigm. Environ. Behav. 2013, 45, 369-398. [CrossRef]

53. Havardi-Burger, N.; Mempel, H.; Bitsch, V. Sustainability Challenges and Innovations in the Value Chain of Flowering Potted Plants for the German Market. Sustainability 2020, 12, 1905. [CrossRef]

54. Park, E.; Luo, Y.; Trouth, F.; Fonseca, J.M. Charting the Future of E-Grocery: An Evaluation of the Use of Digital Imagery as a Sensory Analysis Tool for Fresh Fruits. Horticulturae 2021, 7, 262. [CrossRef] 
55. Stiletto, A.; Rozzanigo, E.; Giampietri, E.; Trestini, S. Taste Beats Reputation in New Food Products Choice: The Case of Ready-to-Eat Pomegranate among Young Consumers in Veneto Region (Italy). Horticulturae 2021, 7, 179. [CrossRef]

56. Demasi, S.; Mellano, M.; Falla, N.; Caser, M.; Scariot, V. Sensory Profile, Shelf Life, and Dynamics of Bioactive Compounds during Cold Storage of 17 Edible Flowers. Horticulturae 2021, 7, 166. [CrossRef] 